\title{
Macrophages and dendritic cells infiltrating islets with or without beta cells produce tumour necrosis factor- $\alpha$ in patients with recent-onset type 1 diabetes
}

\author{
S. Uno • A. Imagawa • K. Okita • K. Sayama • \\ M. Moriwaki • H. Iwahashi • K. Yamagata • S. Tamura • \\ Y. Matsuzawa • T. Hanafusa - J. Miyagawa • \\ I. Shimomura
}

Received: 21 July 2006 / Accepted: 17 November 2006 / Published online: 13 January 2007

(C) Springer-Verlag 2007

\begin{abstract}
Aims/hypothesis Type 1A diabetes results from autoimmune destruction of pancreatic beta cells. We examined the involvement of TNF- $\alpha$ and IL- $1 \beta$, as well as of T cells, macrophages and dendritic cells, in the destruction of beta cells in patients with recent-onset type 1 diabetes.

Materials and methods We obtained pancreatic biopsy specimens from six patients with recent-onset type 1 diabetes and analysed these by immunohistochemistry.
\end{abstract}

S. Uno $\cdot$ A. Imagawa $\cdot$ K. Okita $\cdot$ K. Sayama $\cdot$ H. Iwahashi $\cdot$

K. Yamagata $\cdot$ I. Shimomura

Department of Metabolic Medicine,

Graduate School of Medicine, Osaka University,

Suita, Japan

S. Tamura

Department of Gastroenterology and Hepatology,

Graduate School of Medicine, Osaka University,

Suita, Japan

A. Imagawa $(\bowtie) \cdot T$. Hanafusa

First Department of Internal Medicine, Osaka Medical College,

2-7, Daigaku-machi,

Takatsuki 569-8686, Japan

e-mail: aimag@poh.osaka-med.ac.jp

M. Moriwaki

Department of Internal Medicine, Mino City Hospital,

Mino, Japan

Y. Matsuzawa

Sumitomo Hospital,

Osaka, Japan

J. Miyagawa

Division of Diabetes and Metabolism, Internal Medicine,

Hyogo College of Medicine,

Nishinomiya, Japan
Results $\mathrm{T}$ cell infiltration was less common in islets without beta cells $(12.5[0-33.3] \%)$ than in those with beta cells (46.0 [17.4-83.3]\%), while macrophages and dendritic cells showed a similar extent of infiltration into islets both with or without beta cells. TNF- $\alpha$ was detected in 25.0 (4.3$46.9) \%$ of macrophages and $11.8(0-40.0) \%$ of dendritic cells infiltrating the islets in samples from each patient, but not at all in T cells. IL- $1 \beta$ was detected in $1.8(0-11.3) \%$ of $\mathrm{T}$ cells infiltrating the islets with beta cells, while it was found in $19.2(0-35.3) \%$ of macrophages or $10.7(0-$ $31.3) \%$ of dendritic cells infiltrating the islets in samples from each patient (all values median [range]).

Conclusions/interpretation Macrophages and dendritic cells infiltrate the islets and produce inflammatory cytokines (TNF- $\alpha$ and IL-1 $\beta$ ) during the development of type $1 \mathrm{~A}$ diabetes.

Keywords Biopsy · Dendritic cell $\cdot$ IL- $1 \beta$. Immunohistochemistry $\cdot$ Macrophage $\cdot \mathrm{TNF}-\alpha$
Abbreviations
FITC
fluorescein isothiocyanate
NOD mouse
non-obese diabetic mouse

\section{Introduction}

Type 1A diabetes results from the cell-mediated autoimmune destruction of pancreatic beta cells $[1,2]$. It is a multi-step process that can be divided into three stages. The first stage involves the presentation of beta cell autoantigens by professional antigen-presenting cells. $\mathrm{CD} 4^{+}$ (helper) $\mathrm{T}$ cells subsequently recognise the autoantigens 
Table 1 Patients' profiles

\begin{tabular}{|c|c|c|c|c|c|c|}
\hline $\begin{array}{l}\text { Case } \\
\text { number }\end{array}$ & Age & Sex & $\begin{array}{l}\text { Duration } \\
\text { of } \\
\text { diabetes } \\
\text { (months) }\end{array}$ & $\begin{array}{l}\text { Urinary } \\
\text { C- } \\
\text { peptide } \\
(\mu \mathrm{g} / \text { day })\end{array}$ & $\begin{array}{l}\text { Islet cell } \\
\text { antibodies } \\
\text { (JDF units) }\end{array}$ & $\begin{array}{l}\text { GAD } \\
\text { antibodies }\end{array}$ \\
\hline 1 & 18 & M & 1 & $29-41$ & $<5$ & + \\
\hline 2 & 16 & $\mathrm{~F}$ & 3 & $18-42$ & 640 & - \\
\hline 3 & 24 & M & 2 & $7-14$ & 5 & - \\
\hline 4 & 26 & M & 1 & 5-19 & $<5$ & + \\
\hline 5 & 24 & $\mathrm{~F}$ & 6 & $14-36$ & 5 & + \\
\hline 6 & 34 & M & 7 & 5-19 & 320 & + \\
\hline $\begin{array}{l}\text { Mean } \pm \\
\text { SD }\end{array}$ & $23.7 \pm 6.4$ & & $3.3 \pm 2.6$ & & & \\
\hline
\end{tabular}

JDF, Juvenile Diabetes Federation; M, male; F, female

presented by antigen-presenting cells expressing MHC class II molecules via the $\mathrm{T}$ cell receptor. Finally, $\mathrm{CD} 8^{+}$ (cytotoxic) $\mathrm{T}$ cells, which are activated by Th1 helper $\mathrm{T}$ cells, attack and destroy the pancreatic beta cells.

Several effecter molecules are thought to kill beta cells in the final phase of insulitis, including Fas-Fas ligand, perforin-granzyme and inflammatory cytokines such as TNF- $\alpha$ or IL- $1 \beta[3,4]$. Among them, TNF- $\alpha$ or IL- $1 \beta$ induces apoptotic death of cells from a mouse beta cell line [5] or isolated mouse beta cells [6], while injection of neonatal non-obese diabetic (NOD) mice with a neutralising anti-TNF- $\alpha$ antibody protected against diabetes [7]. Insulitis develops in NOD mice lacking the TNF receptor 1 (TNFR1 or TNFRp55) similarly to in normal NOD mice, but progression to diabetes does not occur in these mice [8]. In addition, treatment with specific neutralising antibodies for IL- $1 \beta$ prevents cyclophosphamide-induced diabetes in NOD mice [9], while IL-1 receptor deficiency slows progression to diabetes in this mouse [10]. Furthermore, prevention of insulitis and diabetes has been achieved in NOD mice by treatment with a recombinant IL-1 receptor antagonist [11]. Finally, we have detected the production of TNF- $\alpha$ and IL- $1 \beta$ in the pancreas of patients with recentonset type 1 diabetes [12]. All of the above findings suggest an important role of these inflammatory cytokines in the destruction of beta cells in vitro and in vivo.

To clarify the significance of inflammatory cytokines in the development of human type 1 diabetes, we investigated the production of these cytokines, as well as the populations of islet-infiltrating $\mathrm{T}$ cells, dendritic cells and macrophages, during and after beta cell destruction in pancreatic biopsy specimens from patients with recent-onset type 1 diabetes.

\section{Subjects and methods}

Subjects We examined six patients with recent-onset type 1 diabetes (four men, two women). All of the patients fulfilled the criteria of the American Diabetes Association and WHO for a diagnosis of type 1 diabetes [13]. The mean age of the patients was $23.7 \pm 6.4$ years (mean $\pm \mathrm{SD}$ ) and the mean duration of diabetes was $3.3 \pm 2.6$ months (mean \pm $\mathrm{SD})$. Islet cell antibodies, GAD antibodies or both types of antibodies were detected in all six patients. Islet cell antibodies and GAD antibodies were identified by indirect immunofluorescence or with a radioimmunoassay kit, respectively (Table 1). Pancreatic body tissues from three patients (two men, one woman) who had gastric cancer and underwent partial pancreatectomy were used as the normal control. The age of control subjects was $52.3 \pm 7.0$ years (mean $\pm \mathrm{SD}$ ), and the glucose tolerance of these subjects was in the normal range before the operation. We have reported part of the histological findings for the type 1 diabetic patients and control subjects previously $[2,14,15]$.

Pancreatic sections The study protocol was approved by the Ethics Committee of Osaka University Medical School and written informed consent was obtained from all patients. Pancreatic biopsy was performed as described previously in the past 16 years and there were no major complications [14]. Briefly, a laparoscope was introduced into the abdominal cavity from an incision near the umbilicus under local anaesthesia. Under direct inspection, one to three pieces of tissue were obtained from the body of
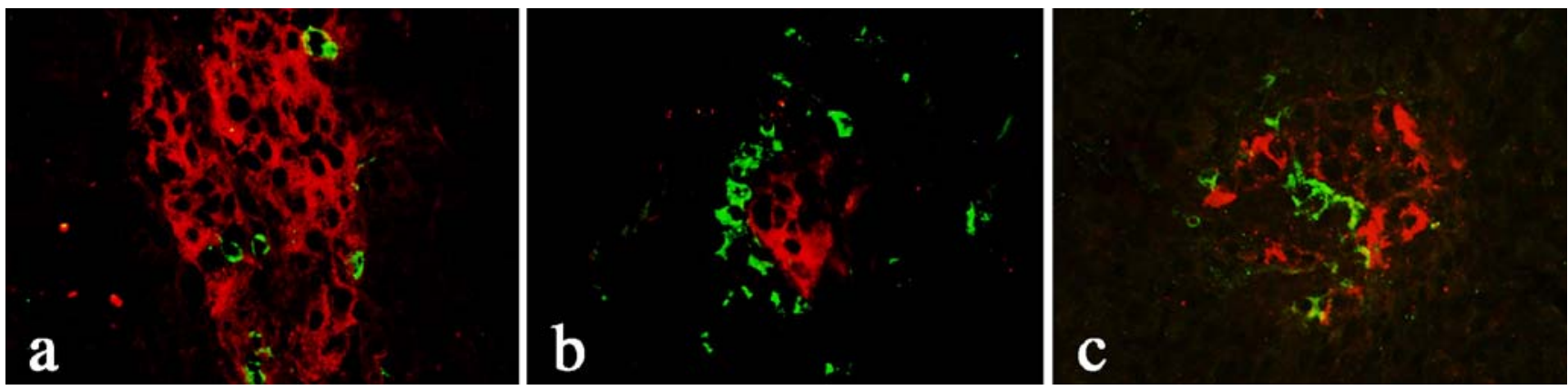

Fig. 1 Pancreatic sections from a patient with recent-onset type 1 diabetes were stained with the following: a anti-insulin antibody (red) and anti-CD3 antibody (green) (case 2); b anti-insulin antibody (red) and anti-CD68 antibody (green) (case 4); and c anti-glucagon antibody (red) and anti-CD11c antibody (green) (case 1). Mononuclear cells are infiltrating the islets 
Table 2 Insulitis for CD3, CD68 and CD11c by immunohistochemical analysis

\begin{tabular}{|c|c|c|c|c|c|c|}
\hline \multirow{3}{*}{$\begin{array}{l}\text { Case } \\
\text { number }\end{array}$} & \multicolumn{6}{|c|}{ Percentage of islets with insulitis for } \\
\hline & \multicolumn{2}{|l|}{$\mathrm{CD} 3$} & \multicolumn{2}{|c|}{ CD68 } & \multicolumn{2}{|c|}{$\mathrm{CD} 11 \mathrm{c}$} \\
\hline & $\begin{array}{l}\text { Beta } \\
\text { cell }^{+}\end{array}$ & $\begin{array}{l}\text { Beta } \\
\text { cell }^{-}\end{array}$ & $\begin{array}{l}\text { Beta } \\
\text { cell }^{+}\end{array}$ & $\begin{array}{l}\text { Beta } \\
\text { cell }^{-}\end{array}$ & $\begin{array}{l}\text { Beta } \\
\text { cell }^{+}\end{array}$ & $\begin{array}{l}\text { Beta } \\
\text { cell }^{-}\end{array}$ \\
\hline 1 & 80.0 & 33.3 & 100 & 57.1 & 80.0 & 35.7 \\
\hline 2 & 55.6 & 0 & 28.9 & 0 & 53.6 & 0 \\
\hline 3 & 36.4 & 12.5 & 50.0 & 60.0 & 0 & 50.0 \\
\hline 4 & 22.7 & 0 & 47.1 & 60.0 & 33.3 & 0 \\
\hline 5 & 17.4 & 0 & 31.0 & 0 & 16.3 & 40.0 \\
\hline 6 & 83.3 & 0 & 91.7 & 41.3 & ND & 20.0 \\
\hline
\end{tabular}

Data are shown in percentage of insulitis-positive islets in examined islets. Beta cell ${ }^{+}$, islets with beta cells; Beta cell ${ }^{-}$, islets without beta cells; $\mathrm{ND}$, not determined

the pancreas with biopsy forceps. Blocks of these biopsy specimens (20-40 $\mathrm{mg}$ in each patient) were immediately frozen in dry ice-isopentane, and 5- $\mu \mathrm{m}$ thick sections were cut on a cryostat. About 300 consecutive sections were cut from each biopsy specimen and stored at $-80^{\circ} \mathrm{C}$ until use. Haematoxylin and eosin staining was performed in every 11th cryostat section to detect islets. Control tissues were prepared in the same manner as the biopsy specimens.

Immunohistochemistry We used a double-immunofluorescence method to detect insulitis, mononuclear cell infiltration into the islets and production of TNF- $\alpha$ or IL- $1 \beta$. After drying in air, the frozen sections were fixed in ice-cold acetone for $15 \mathrm{~min}$ and washed three times for a total of 15 min in PBS, pH 7.4. Endogenous biotin was blocked with a biotin blocking system (Dako Japan, Kyoto, Japan). Then the sections were incubated overnight at $4{ }^{\circ} \mathrm{C}$ with one of the following primary antibodies: anti-human CD3 (T34B5; Dako Japan), anti-human CD68 (EBM11; Dako Japan) or anti-human CD11c (BU15; Immunotech, Marseille, France). After washing in PBS, the sections were incubated for $60 \mathrm{~min}$ at room temperature with biotinylated horse anti-mouse immunoglobulins (Vector Laboratories, Burlingame, CA, USA), and then for an additional $40 \mathrm{~min}$ with fluorescein isothiocyanate (FITC)-conjugated avidin (Vector Laboratories). These procedures were followed by incubation with guinea-pig anti-insulin antibodies (Dako Japan) or rabbit anti-glucagon antibodies (kindly provided by S. Iwasa, Takeda Chemical, Osaka, Japan) and incubation with the corresponding secondary antibody, rhodamine-conjugated anti-guinea-pig immunoglobulins (Chemicon International, Temecula, CA, USA) or Texas Red-conjugated anti-rabbit immunoglobulins (Amersham Pharmacia Biotech, Bucks, UK). After each incubation, the sections were washed three times with PBS.

Production of TNF- $\alpha$ and/or IL-1 $\beta$ was visualised by double immunofluorescence staining. First, staining was performed with anti-recombinant human TNF- $\alpha$ antibody or anti-recombinant human IL-1 $\beta$ antibody (R\&D Systems, Minneapolis, MN, USA), biotinylated rabbit anti-goat immunoglobulins (Vector Laboratories) and rhodamineconjugated avidin (Vector Laboratories). The sections were incubated with biotinylated rabbit anti-goat immunoglobulins for $60 \mathrm{~min}$ at room temperature and then for an additional $40 \mathrm{~min}$ with rhodamine-conjugated avidin. Next, the sections were blocked with an avidin-biotin blocking system (Dako Japan), washed in PBS and incubated with primary antibodies targeting $\mathrm{T}$ cells $(\mathrm{CD} 3)$, macrophages (CD68) or dendritic cells (CD11c). After washing in PBS, the sections were incubated for $60 \mathrm{~min}$ at room temperature with biotinylated horse anti-mouse immunoglobulins (Vector Laboratories) and then for an additional $40 \mathrm{~min}$ with FITC-conjugated avidin (Vector Laboratories). To achieve localisation of the islets, staining for insulin or glucagon was done with the adjacent serial section.

Each section was washed in PBS, and mounted in aqueous mounting medium (Perma Fluor; Immunon, Pittsburgh, PA, USA) before being observed under a fluorescence microscope with epi-illumination (Olympus, Tokyo, Japan).


Fig. 2 Pancreatic sections from a patient with recent-onset type 1 diabetes were stained with the following: a anti-TNF- $\alpha$ antibody (red) and anti-CD3 antibody (green) (case 3); b anti-TNF- $\alpha$ antibody (red) and anti-CD68 antibody (green) (case 6); and $\mathbf{c}$ anti-TNF- $\alpha$ antibody

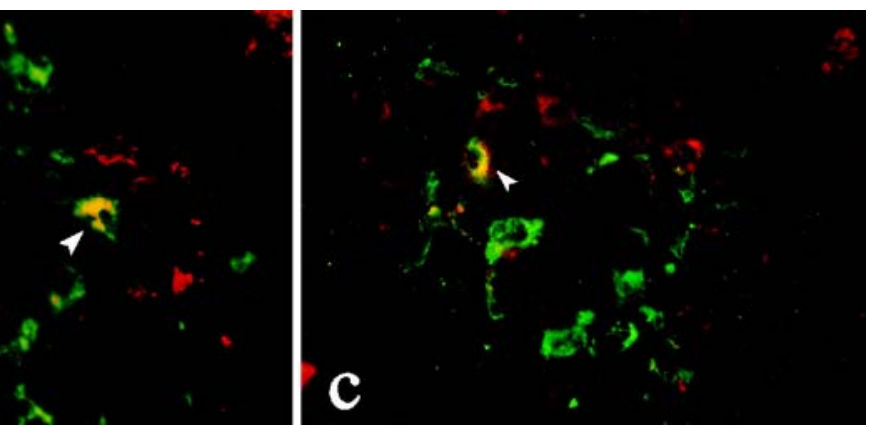

(red) and anti-CD11c antibody (green) (case 3). TNF- $\alpha$ was detected in CD68-positive cells and CD11c-positive cells. Arrowheads b, c, representative double positive cells 
Table 3 TNF- $\alpha$ levels for mononuclear cells infiltrating the islets

\begin{tabular}{llcc}
\hline Case number & CD3 & CD68 & CD11c \\
\hline 1 & 0 & 27.8 & 0 \\
2 & 0 & 4.3 & 13.6 \\
3 & 0 & 46.9 & 10.0 \\
4 & 0 & 20.0 & 20.0 \\
5 & 0 & 22.2 & 10.0 \\
6 & 0 & 29.9 & 40.0 \\
\hline
\end{tabular}

Data are shown in percentage of TNF- $\alpha$-positive mononuclear cells in the islets with insulitis. TNF- $\alpha$ was produced more frequently in CD68-positive cells $(p<0.01)$ and CD11c-positive cells $(p<0.01)$ than in CD3-positive cells

We examined 26-54 sections to detect mononuclear cell infiltration of islets and the production of cytokines in each subject.

Data are presented as the percentage of cytokine-positive cells with each cell surface marker in double immunofluorescence-stained sections.

Statistical analysis The significance of differences between two groups was evaluated by the Mann-Whitney $U$ test and a $p$ value of less than 0.05 was taken to indicate the presence of a statistically significant difference.

\section{Results}

Phenotypic analysis of mononuclear cells infiltrating the islets Pancreatic islets were detected in all the type 1 diabetic patients. Light microscopic examination of haematoxylin and eosin staining sections revealed that most of these islets were small and atrophic as compared with islets in normal pancreas. When islets with two or more infiltrating mononuclear cells were defined as insulitis-positive, 10-60
Table 4 IL-1 $\beta$ levels for mononuclear cells infiltrating the islets

\begin{tabular}{lccc}
\hline Case number & CD3 & CD68 & CD11c \\
\hline 1 & 1.9 & 35.3 & 28.8 \\
2 & 1.6 & 0 & 6.3 \\
3 & 10.0 & 21.7 & 0 \\
4 & 0 & 16.7 & 31.3 \\
5 & 0 & 5.6 & 12.2 \\
6 & 11.3 & 21.8 & 9.1 \\
\hline
\end{tabular}

Data are shown in percentage of IL- $1 \beta$-positive mononuclear cells in the islets with insulitis

insulitis-positive islets were identified in the six patients by the double immunofluorescence method (Fig. 1). Infiltration of T cells, macrophages and dendritic cells was detected in $36.7(15.4-66.7) \%, 49.0(27.7-68.4) \%$ and $34.5(18.8$ $47.4) \%$ of samples from each patient. Comparison between islets with beta cells and islets without beta cells showed infiltration of $46.0(17.4-83.3) \%$ vs $12.5(0-33.3) \%$ by $\mathrm{T}$ cells $(p<0.01), 48.6(28.9-100) \%$ vs $49.2(0-60.0) \%$ by macrophages (NS) and $33.3(0-80.0) \%$ vs $35.7(0-50.0) \%$ by dendritic cells (NS; all above values median [range]) (Table 2). In contrast, no insulitis-positive islets at all were observed in three control subjects.

Production of TNF- $\alpha$ TNF- $\alpha$ was detected in the islets of all six patients (Fig. 2). TNF- $\alpha$-positive cells were detected in 3.5 to $54.5 \%$ of the islets with insulitis, and production of TNF- $\alpha$ was identified both inside and around the islets. Although TNF- $\alpha$ production was not seen in T cells, it was found in 25.0 (4.3-46.9)\% of macrophages and $11.8(0$ $40.0) \%$ of dendritic cells in samples from each patient (values median [range]) (Table 3). The prevalence of TNF$\alpha$-positive macrophages or dendritic cells was $22.2 \%$ in islets with T cell infiltration and $24.5 \%$ in those without. On the other hand, TNF- $\alpha$-positive cells were not detected in the 110 islets from three control subjects.
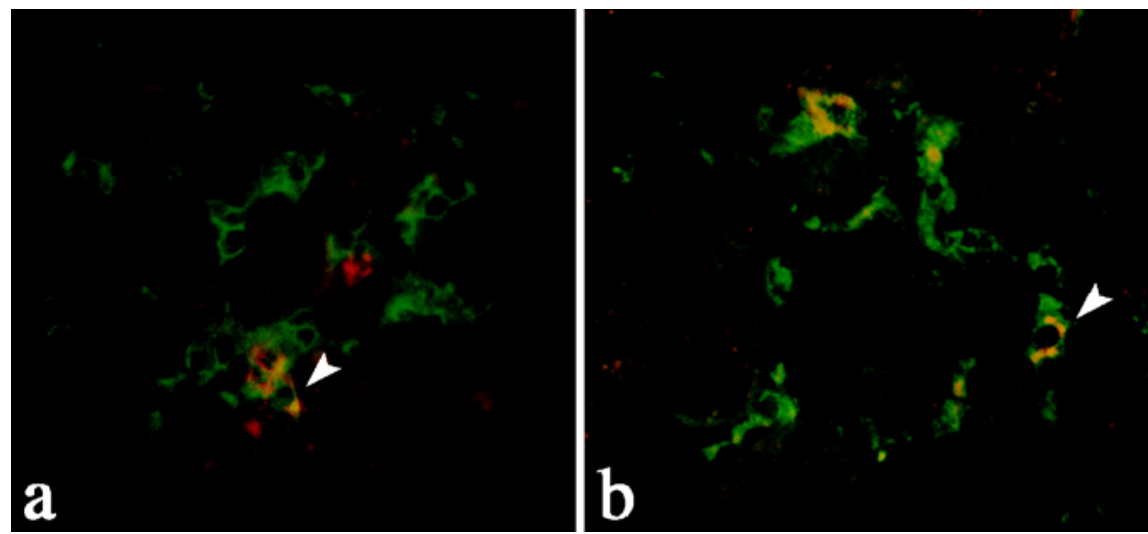

Fig. 3 Pancreatic sections from a patient with recent-onset type 1 diabetes were stained with the following: a anti-IL-1 $\beta$ antibody (red) and anti-CD3 antibody (green) (case 1); b anti-IL-1 $\beta$ antibody (red) and anti-CD68 antibody (green) (case 5); and $\mathbf{c}$ anti-IL-1 $\beta$ antibody

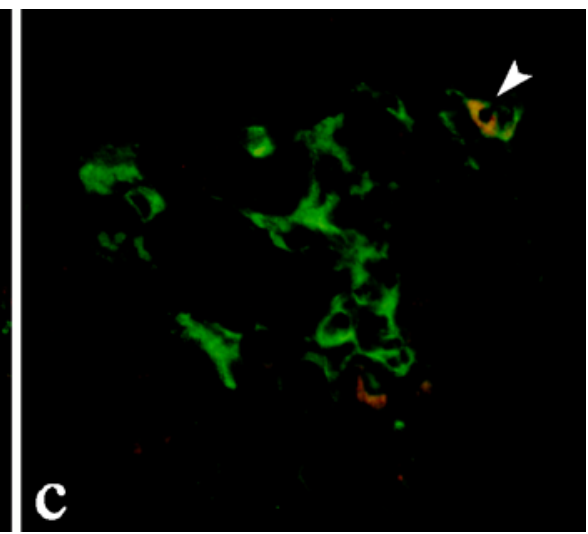

(red) and anti-CD11c antibody (green) (case 1). IL-1 $\beta$ was detected in CD3-positive cells, CD68-positive cells and CD11c-positive cells. Arrowheads indicate representative double positive cells 
Production of IL-1 $\beta$ IL- $1 \beta$ was detected in the islets of all six patients (Fig. 3). IL-1 $\beta$-positive cells were detected in 12.5 to $47.6 \%$ of the islets with insulitis, and production of IL- $1 \beta$ was identified both inside and around the islets. IL$1 \beta$ was produced by $1.8(0-11.3) \%$ of $\mathrm{T}$ cells, but by 19.2 $(0-35.3) \%$ of macrophages and $10.7(0-31.3) \%$ of dendritic cells in samples from each patient (values median [range]) (Table 4). The prevalence of IL-1 $\beta$-positive macrophages or dendritic cells was $19.1 \%$ in islets with T cell infiltration and $40.5 \%$ in those without. On the other hand, IL- $1 \beta$ positive cells were not detected in the 116 islets from three control subjects.

\section{Discussion}

This study reveals the source of inflammatory cytokines (TNF- $\alpha$ and IL-1 $\beta$ ) and the populations of islet-infiltrating cells in patients with recent-onset type 1 diabetes and insulitis.

The main source of TNF- $\alpha$ and IL- $1 \beta$ in the islets was not $\mathrm{T}$ cells, but islet-infiltrating dendritic cells and macrophages. We have two hypotheses about the role of these cytokines in the beta cell destruction that occurs in human type 1 diabetes. First, these cytokines directly damage beta cells, as shown in studies in vitro, in which these two cytokines acted synergistically to damage beta cells and induce their apoptosis [5]. Second, these cytokines damage beta cells via beta cell-T cell interaction. It has been reported that IL$1 \beta$ induces production of Fas on the beta cell surface [16], and islet-infiltrating $\mathrm{T}$ cells can destroy beta cells via the Fas-Fas ligand system [17]. In the present study, T cells were detected only in islets with beta cells, whereas TNF$\alpha$ - or IL- $1 \beta$-positive dendritic cells/macrophages were detected both in islets with and without beta cells, suggesting these cytokines could damage beta cells without the interaction of $\mathrm{T}$ cells and beta cells. The higher prevalence of TNF- $\alpha$ - or IL-1 $\beta$-positive dendritic cells/ macrophages in the islets without $\mathrm{T}$ cell infiltration than in those with infiltration also supports the first hypothesis.

$\mathrm{T}$ cells in this study were mainly observed in the islets with beta cells, while dendritic cells and macrophages were found in both islets with or without beta cells, suggesting that beta cells are mainly destroyed by $\mathrm{T}$ cells in the development of human type 1 diabetes. Only a few infiltrating $\mathrm{T}$ cells were detected in the islets of NOD mice after the onset of overt diabetes [18]. The main target of these cells is thought to be insulin [19], so such findings would be reasonable, because the $\mathrm{T}$ cell target has already been destroyed.

This study also made it clear that CD11c-positive dendritic cells infiltrate islets of type 1 diabetic patients with insulitis. CD11c-positive cells are reported to have strong antigen-presenting activity in mice and humans [20]. In the NOD mouse, an animal model of autoimmune type 1 diabetes, CD11c-positive cells are found to infiltrate pancreatic islets from a very early stage until the late stage of insulitis [21]. Of course, our biopsy specimens were taken after the onset of overt diabetes, which means that we detected the CD11c-positive dendritic cells in the late stage of insulitis in human type 1 diabetes. The reason why dendritic cells were still in the islets after beta cells had already been destroyed remains to be clarified.

In conclusion, the present study demonstrated that macrophages and dendritic cells infiltrate the pancreatic islets and produce inflammatory cytokines (TNF- $\alpha$ and IL$1 \beta$ ) during the development of type $1 \mathrm{~A}$ diabetes.

Acknowledgements This study was supported by a grant-in-aid from the Japanese Society for the Promotion of Science and a grantin-aid from the Japan Diabetes Foundation. We are indebted to Y. Okada and H. Mori in the Department of Pathology, Osaka Medical College for their kind help in immunohistochemistry, and to F. Katsube in the Department of Metabolic Medicine, Graduate School of Medicine, Osaka University for her skilful technical assistance.

Duality of interest The authors declare that they have no duality of interest.

\section{References}

1. Eisenbarth GS (1986) Type I diabetes mellitus. A chronic autoimmune disease. N Engl J Med 314:1360-1368

2. Hanafusa T, Miyazaki A, Miyagawa J et al (1990) Examination of islets in the pancreas biopsy specimens from newly diagnosed type 1 (insulin-dependent) diabetic patients. Diabetologia 33:105111

3. Thomas HE, Darwiche R, Corbett JA, Kay TW (1999) Evidence that beta cell death in nonobese diabetic mouse is Fas independent. J Immunol 163:1562-1569

4. Jiang Z, Woda BA (1991) Cytokine gene expression in the islets of the diabetic Biobreeding/Worcester rat. J Immunol 146:2990 2994

5. Iwahashi H, Hanafusa T, Eguchi Y et al (1996) Cytokine-induced apoptotic cell death in a mouse pancreatic beta-cell line: inhibition by Bcl-2. Diabetologia 39:530-536

6. Corbett JA, Wang JL, Sweetland MA, Lancaster JR Jr, McDaniel ML (1992) Interleukin-1 beta induces the formation of nitric oxide by beta-cells purified from rodent islets of Langerhans. Evidence for the beta-cell as a source and site of action of nitric oxide. J Clin Invest 90:2384-2391

7. Yang XD, Tisch R, Singer SM et al (1994) Effect of tumor necrosis factor alpha on insulin-dependent diabetes mellitus in NOD mice. 1. The early development of autoimmunity and the diabetogenic process. J Exp Med 180:995-1004

8. Kagi D, Ho A, Odermatt B, Zakarian A, Ohashi PS, Mak TW (1999) TNF receptor 1-dependent beta cell toxicity as an effector pathway in autoimmune diabetes. J Immunol 162:4598-4605

9. Cailleau C, Diu-Hercend A, Ruuth E, Westwood R, Carnaud C (1997) Treatment with neutralizing antibodies specific for ILlbeta prevents cyclophosphamide-induced diabetes in nonobese diabetic mice. Diabetes 46:937-940 
10. Thomas HE, Irawaty W, Darwiche R et al (2004) IL-1 receptor deficiency slows progression to diabetes in the NOD mouse. Diabetes 53:113-121

11. Sandberg JO, Eizirik DL, Sandler S (1997) IL-1 receptor antagonist inhibits recurrence of disease after syngeneic pancreatic islet transplantation to spontaneously diabetic non-obese diabetic (NOD) mice. Clin Exp Immunol 108:314-317

12. Yamagata K, Nakajima H, Tomita K et al (1996) Dominant TCR alpha-chain clonotypes and interferon-gamma are expressed in the pancreas of patients with recent-onset insulin-dependent diabetes mellitus. Diabetes Res Clin Pract 34:37-46

13. Alberti KG, Zimmet PZ (1998) Definition, diagnosis and classification of diabetes mellitus and its complications. Part 1: diagnosis and classification of diabetes mellitus. Provisional report of a WHO consultation. Diabet Med 15:539-553

14. Imagawa A, Hanafusa T, Tamura S et al (2001) Pancreatic biopsy as a procedure for detecting in situ autoimmune phenomena in type 1 diabetes: close correlation between serological markers and histological evidence of cellular autoimmunity. Diabetes 50:1269-1273

15. Itoh N, Hanafusa T, Miyazaki A et al (1993) Mononuclear cell infiltration and its relation to the expression of major histocompatibility complex antigens and adhesion molecules in pancreas biopsy specimens from newly diagnosed insulin-dependent diabetes mellitus patients. J Clin Invest 92:2313-2322

16. Stassi G, Todaro M, Richiusa $P$ et al (1995) Expression of apoptosis-inducing CD95 (Fas/Apo-1) on human beta-cells sorted by flow-cytometry and cultured in vitro. Transplant Proc 27:3271-3275

17. Moriwaki M, Itoh N, Miyagawa J et al (1999) Fas and Fas ligand expression in inflamed islets in pancreas sections of patients with recent-onset type 1 diabetes mellitus. Diabetologia 42:1332-1340

18. Calafiore R, Pietropaolo M, Basta G, Falorni A, Picchio ML, Brunetti P (1993) Pancreatic beta-cell destruction in non-obese diabetic mice. Metabolism 42:854-859

19. Nakayama M, Abiru N, Moriyama H et al (2005) Prime role for an insulin epitope in the development of type 1 diabetes in NOD mice. Nature 435:151-152

20. Banchereau J, Steinman RM (1998) Dendritic cells and the control of immunity. Nature 392:245-252

21. Dahlen E, Dawe K, Ohlsson L, Hedlund G (1998) Dendritic cells and macrophages are the first and major producers of TNF-alpha in pancreatic islets in the nonobese diabetic mouse. J Immunol 160:3585-3593 